\title{
The Prevention and Treatment of Obesity
}

\author{
Alfred Wirth, Martin Wabitsch, Hans Hauner
}

\section{SUMMARY}

Background: The high prevalence of obesity ( $24 \%$ of the adult population) and its adverse effects on health call for effective prevention and treatment.

Method: Pertinent articles were retrieved by a systematic literature search for the period 2005 to 2012. A total of 4495 abstracts were examined. 119 publications were analyzed, and recommendations were issued in a structured consensus procedure by an interdisciplinary committee with the participation of ten medical specialty societies.

Results: Obesity (body-mass index [BMI] $\geq 30 \mathrm{~kg} / \mathrm{m}^{2}$ ) is considered to be a chronic disease. Its prevention is especially important. For obese persons, it is recommended that a diet with an energy deficit of $500 \mathrm{kcal} / \mathrm{day}$ and a low energy density should be instituted for the purpose of weight loss and stabilization of a lower weight. The relative proportion of macronutrients is of secondary importance for weight loss. If the BMI exceeds $30 \mathrm{~kg} / \mathrm{m}^{2}$, formula products can be used for a limited time. More physical exercise in everyday life and during leisure time promotes weight loss and improves risk factors and obesity-associated diseases. Behavior modification and behavioral therapy support changes in nutrition and exercise in everyday life. With respect to changes in lifestyle, there is no scientific evidence to support any particular order of the measures to be taken. Weight-loss programs whose efficacy has been scientifically evaluated are recommended. Surgical intervention is more effective than conservative treatment with respect to reduction of bodily fat, improvement of obesity-associated diseases, and lowering mortality. Controlled studies indicate that, within 1 to 2 years, a weight loss of ca. 4 to $6 \mathrm{~kg}$ can be achieved by dietary therapy, 2 to $3 \mathrm{~kg}$ by exercise therapy, and 20 to $40 \mathrm{~kg}$ by bariatric surgery.

Conclusion: There is good scientific evidence for effective measures for the prevention and treatment of obesity.

\section{$\checkmark$ Cite this as:}

Wirth A, Wabitsch M, Hauner H: Clinical practice guideline:

The prevention and treatment of obesity. Dtsch Arztebl Int 2014; 111:

705-13. DOI: 10.3238/arztebl.2014.0705
Bad Rothenfelde: Prof. Dr. med. Wirth

Department of Pediatrics and Adolescent Medicine, Section of Pediatric Endocrinology and Diabetes, University Medical Center Ulm, Ulm: Prof. Dr. med. Wabitsch

Else Kroener-Fresenius-Center for Nutritional Medicine, Klinikum rechts der Isar, Technische Universität München, Munich: Prof. Dr. med. Hauner
O besity is a significant issue for health policy because it is so widespread in the population as a whole, and because of the high risk of complications it carries (1). According to the findings of the DEGS study (Studie zur Gesundheit Erwachsener in Deutschland, German Health Interview and Examination Survey for Adults) carried out between 2008 and 2011 by the Robert Koch Institute in a cohort representative of the whole population, $23.3 \%$ of men and $23.9 \%$ of women were obese (2). The prevalence of obesity increases four-fold with age in both men and women in an age-dependent manner. In the period from 1999 to 2009 , in particular, the prevalence of persons with a body mass index (BMI) of $35 \mathrm{~kg} / \mathrm{m}^{2}$ or higher rose markedly (3).

Obesity is implicated in a wide variety of health problems such as impaired sense of wellbeing and impaired quality of life, numerous complications, high frequency of sick leave and early retirement, and increased mortality. The health-related complications are due to the increased proportion of body fat and associated disturbances of endocrine/metabolic function and due to increased mechanical load. Fatty tissue does not only store energy, it is also an active endocrine organ that is closely connected to the intermediary metabolism.

\section{Method}

Twelve experts from ten medical professional societies/ organizations took part in developing the Guideline $(e B o x)$. The literature search and evaluation of the evidence were carried out by the German Agency for Quality in Medicine (ÄZQ, Ärztliches Zentrum für Qualität in der Medizin) on behalf of the German Obesity Association (DAG, Deutsche AdipositasGesellschaft). Five guidelines identified as relevant were evaluated using the German instrument for the methodical evaluation of guidelines (DELBI, Deutsches Leitlinien-Bewertungsinstrument) and the key recommendations extracted. A total of 4495 abstracts were identified as published during the period covered by the literature search (from 2005 to March 2012). The MedLine database was searched via www. pubmed.org. In addition, other relevant publications dated up to April 2014 and located by the experts in a manual search were taken into account, so it may be assumed that no studies were missed that would fundamentally undermine the statements contained in the 
FIGURE 1

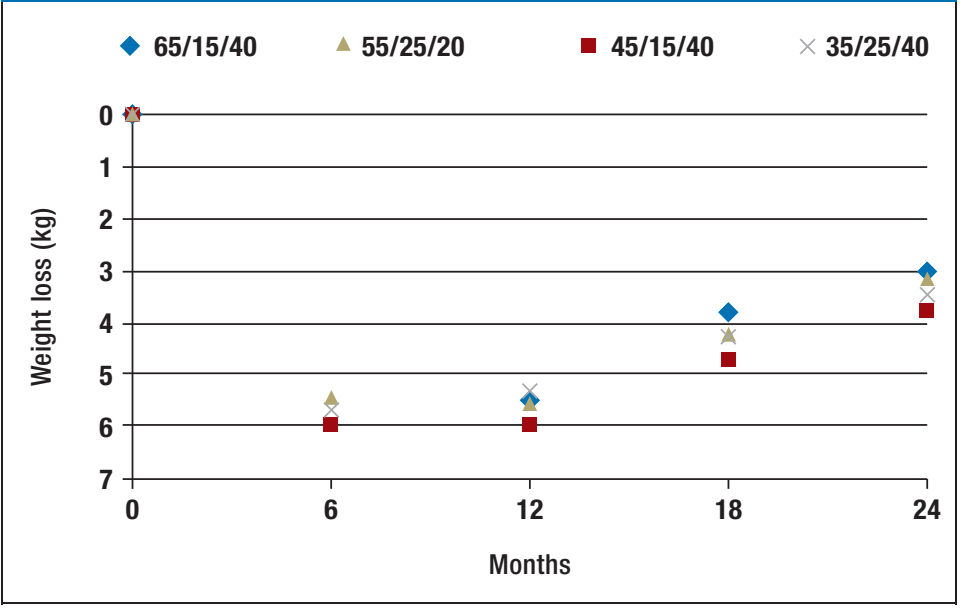

Weight loss on four different types of diet with different ratios of macronutrients. Study in 811 men and women (BMl 25 to $40 \mathrm{~kg} / \mathrm{m}^{2}$ ) aged 30 to 70 years and with various carbohydrate:protein:fat ratios (\%) (13). that have a low energy density due to their high water or fiber content, such as wholegrain products, fruit, and vegetables, are comparatively more filling and have a low energy content (4). According to the German College of General Practitioners and Family Physicians (DEGAM, Deutsche Gesellschaft für Allgemeinmedizin und Familienmedizin), there is insufficient evidence to support the proposition that persons with a BMI over $25 \mathrm{~kg} / \mathrm{m}^{2}$ should avoid energy-dense foods. The German Society of Nutritional Medicine (DGEM, Deutsche Gesellschaft für Ernährungsmedizin) also says that a Mediterranean diet helps prevent overweight and obesity.

The Guideline also states that consumption of alcohol, fast food, and sugary drinks should be reduced (EL $2, R G B)(5)$. Fast food often contains a high proportion of fat and sugar and is thus very energy-dense (6). Not only drinks sweetened with sugar, but fruit juices and juice-based drinks too, have a high sugar content and are not very filling (7).

An inactive lifestyle with frequent sitting watching television or on the internet and similar activities promotes weight gain (EL 1-4, RG B). Getting exercise in everyday activities and as a leisure pursuit has a preventive effect. This goal is best achieved by endurancefocused physical exercise (use of large muscle groups) for more than 2 hours per week (8).

(eFigure). The selection (defined inclu and exclusion criteria) and evaluation of the studies (in accordance with SIGN, the Scottish Intercollegiate Guidelines Network, eTable) were carried out by personnel of the ÄZQ. The recommendations formulated on the basis of the evidence tables and source guidelines were agreed during structured consensus conferences and during the Delphi process that followed (moderated by the ÄZQ). The final version of the Guideline was produced after external expert review.

The statements below reproduce the main content of the Guideline. The complete texts are available at www.adipositas-gesellschaft.de.

\section{Obesity-a disease}

The World Health Organization (WHO), the German Federal Court, the European Parliament, and the German Obesity Association regard obesity as a chronic disease caused by a complex interaction between genetic factors and environmental or lifestyle factors, which carries increased morbidity and mortality and needs lifelong treatment. Because it is a heterogeneous disorder, individualized assessment, risk stratification, and treatment are required.

\section{Prevention of obesity}

Given that obesity is so prevalent, and given how difficult it is to treat, prevention is particularly important. To prevent overweight and obesity, people should eat and drink according to their nutritional needs, get regular exercise, and check their weight regularly (evidence level [EL] 1-4, recommendation grade [RG] A, eTable). So far as nutrition is concerned, they should consume less food with a high energy density and more food with a low energy density (EL 2, RG B). Foods

\section{Who should lose weight?}

Whether treatment is indicated for overweight and obesity depends on patient BMI and body fat distribution, taking into account any co-morbidities, risk factors, and patient preferences (EL 4, RG A). The following are indicators for treatment:

- $\mathrm{BMI} \geq 30 \mathrm{~kg} / \mathrm{m}^{2}$ (obesity)

- BMI of 25 to $30 \mathrm{~kg} / \mathrm{m}^{2}$ (overweight) with concomitant

- overweight-related health impairments (e.g., hypertension, type 2 diabetes mellitus) or

- abdominal obesity or

- diseases that are exacerbated by overweight or

- high psychosocial distress.

Weight loss is contraindicated for persons with wasting diseases and for pregnant women.

\section{Treatment for obesity \\ Goals}

Treatment goals should be realistic and adapted to the individual patient (e.g., experiences, resources, risks) (EL 4, RG B). Goals are:

- Long-term weight reduction: - BMI 25 to $35 \mathrm{~kg} / \mathrm{m}^{2}:>5 \%$ of initial weight

- BMI $>35 \mathrm{~kg} / \mathrm{m}^{2}:>10 \%$ of initial weight

- Improvement in obesity-related risk factors

- Reduction in obesity-related diseases

- Lowering of risk of early death

- Prevention of inability to work and early retirement

- Reduction of psychosocial disorders

- Improvement of quality of life 
Effect of various forms of dietary therapy on body weight in overweight/obese persons*

\begin{tabular}{|c|c|c|c|c|}
\hline No. of participants & Study type & Duration & Effect & Reference \\
\hline \multicolumn{5}{|l|}{ Low-fat diet only } \\
\hline 1910 & Meta-analysis of 19 RCTs in adults & $2-12$ months & $\begin{array}{l}-3.2 \mathrm{~kg}(-1.9 \text { to }-4.5 \mathrm{~kg}) \\
\text { extra weight loss } \mathrm{t}(-2.6 \mathrm{~kg}) \text { per } 10 \mathrm{~kg} \text { higher } \\
\text { weigh }\end{array}$ & $(10)$ \\
\hline \multicolumn{5}{|l|}{ Dietary therapy } \\
\hline $\begin{array}{l}6386 \text { intervention } \\
5407 \text { "usual care" }\end{array}$ & Meta-analysis of $46 \mathrm{RCTs}$ & $>4$ months & $\begin{array}{l}\text { Weight reduced by } 1.9 \mathrm{BMI} \text { units } \\
\text { or } 6 \% \text { of initial weight }\end{array}$ & (14) \\
\hline \multicolumn{5}{|c|}{ Low-carbohydrate vs. low-fat weight reduction diet } \\
\hline 447 & Meta-analysis of $5 \mathrm{RCTs}$ & $\begin{array}{l}6 \text { months, } 12 \\
\text { months }\end{array}$ & $\begin{array}{l}\text { After } 6 \text { months: } \\
\text { greater weight loss of }-3.3 \mathrm{~kg} \\
(-5.3 \text { to }-1.4 \mathrm{~kg}) \text { on low-carbohydrate diet; } \\
\text { after } 12 \text { months: } \\
\text { difference in weight no longer seen } \\
(-1.0 \mathrm{~kg}[-3.5 \text { to } 1.0 \mathrm{~kg}, \text { n.s. }])\end{array}$ & (11) \\
\hline \multicolumn{5}{|c|}{ High-protein vs. low-protein diet } \\
\hline 1086 & Meta-analysis of $15 \mathrm{RCTs}$ & n.d. & $\begin{array}{l}\text { High-protein diet leads to a greater reduction } \\
\text { in body weight, by } \\
-0.39 \mathrm{~kg}(-1.43 \text { to } 0.65 \mathrm{~kg}, \mathrm{n.s} \text {. })\end{array}$ & (15) \\
\hline \multicolumn{5}{|l|}{ Mediterranean diet } \\
\hline 3436 & Meta-analysis of 16 RCTs in adults & n.d. & $\begin{array}{l}\text { All studies: } \\
-1.75 \mathrm{~kg}(-2.86 \text { to }-0.64 \mathrm{~kg}) \\
\text { studies with restricted calories: } \\
-3.88 \mathrm{~kg}(-6.54 \text { to }-1.21 \mathrm{~kg})\end{array}$ & $(16)$ \\
\hline \multicolumn{5}{|c|}{ Recent original data } \\
\hline 811 & $\begin{array}{l}\text { RCT, } \\
\text { various combinations of macronutrients: } \\
20 \% \mathrm{~F} / 15 \% \mathrm{P} / 65 \% \\
\mathrm{CH} 20 \% \mathrm{~F} / 25 \% \mathrm{P} / 55 \% \\
\mathrm{CH} 40 \% \mathrm{~F} / 15 \% \mathrm{P} / 45 \% \\
\mathrm{CH} 40 \% \mathrm{~F} / 25 \% \mathrm{P} / 35 \% \mathrm{CH}\end{array}$ & 24 months & $\begin{array}{l}\text { After } 6 \text { months, } \\
\text { weight loss of } 6 \mathrm{~kg} \text { in all arms, } \\
\text { after } 2 \text { years moderate weight loss of } 4 \mathrm{~kg} \text {, } \\
\text { no difference between diets }\end{array}$ & (13) \\
\hline 772 & $\begin{array}{l}\text { RCT, commercial group program } \\
\text { vs. "standard care" under family doctor }\end{array}$ & 12 months & $\begin{array}{l}-5.1 \text { vs. }-2.25 \mathrm{~kg} \text { (LOCF), } \\
\text { dropout rate: } 42 \%\end{array}$ & (28) \\
\hline
\end{tabular}

*Meta-analyses and RCTs were chosen for quality based on number of participants, study duration, control intervention, and variables measured/measuring methods. n.d., not given; F, fat; P, protein; CH, carbohydrate; LOCF, last observation carried forward; n.s. not significant; RCT, randomized controlled trial

\section{Dietary therapy}

Obese individuals should received personalized nutritional recommendations adapted to their therapeutic goals and risk profile (EL 4, RG A). This can only be successful over the long term if the patient agrees to a change in lifestyle and recommendations that are practicable in daily life. No valid studies have been published on this recommendation.

To carry out dietary therapy, nutritional counseling (individual or in groups) should be offered within the program of medical management (EL 1, RG A). Group sessions are usually more effective than individual sessions. The DGEM gives a recommendation grade of $\mathrm{B}$ rather than $\mathrm{A}$.

For weight reduction, patients should be recommended forms of nutrition that over a long enough time lead to an energy deficit but do not impair health (EL 1-4, RG A).

To reduce body weight, the aim should be to follow a reduction diet that will produce an energy deficit of about $500 \mathrm{kcal} / \mathrm{day}$, or more in individual cases (EL $1-4$, RG B). To achieve this, various nutrition strategies may be employed (EL 1-4, RG 0):

- Reduce fat consumption

- Reduce carbohydrate consumption

- Reduce both fat and carbohydrate consumption

The DGEM states that wide-ranging literature exists for this recommendation and a recommendation grade of $A$ is justified.

An energy deficit of 500 to $600 \mathrm{kcal} /$ day will allow weight loss to occur at around $0.5 \mathrm{~kg} /$ week over a period of 12 up to a maximum of 24 weeks (9). The 


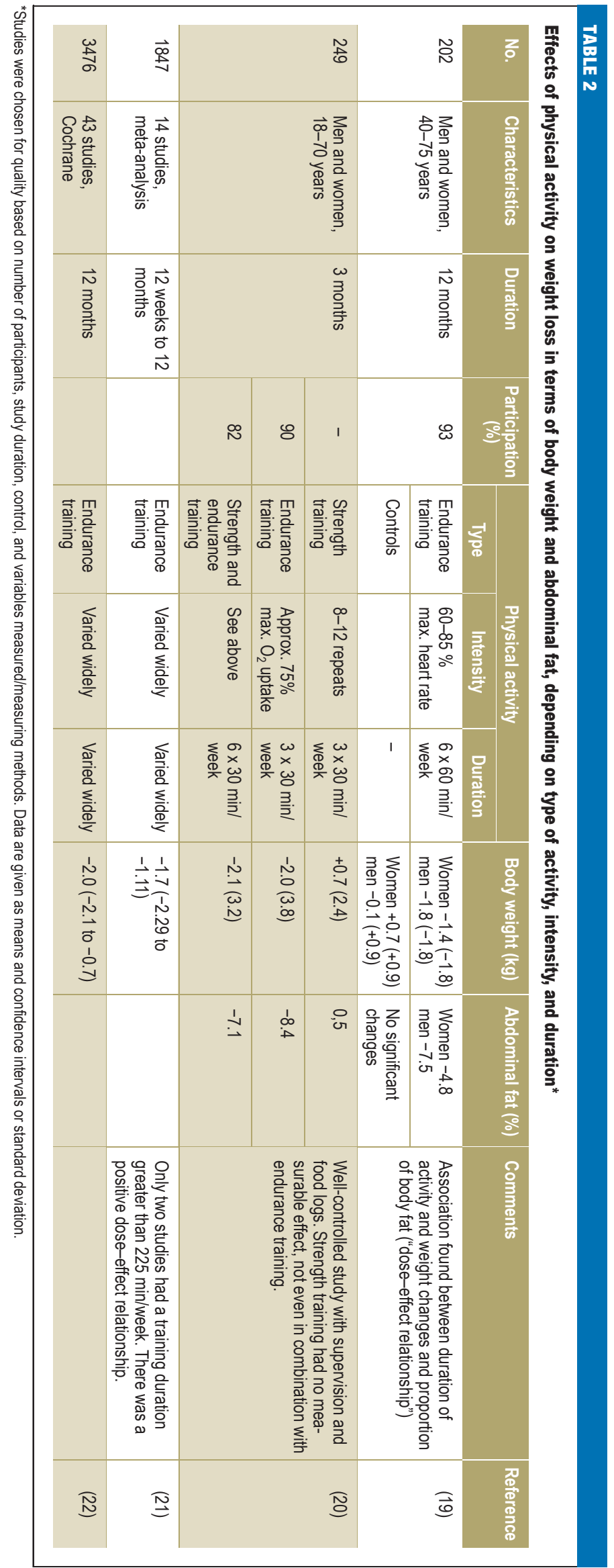

consumption of fat, which in Germany is still high, can be reduced by simple steps (10). A low-carb diet will lead to sharper weight loss at the beginning than other diets, but after a year the difference can no longer be seen (11). Several large studies in the past few years have shown convincingly that the macronutrient composition (ratio of fats to carbohydrates to protein) has no relevance for weight loss (Figure 1) $(12,13)$. Various reduction diets (fat reduction alone, low-carb diet, reduced-energy balanced diet, Mediterranean diet) lead to loss of around $4 \mathrm{~kg}$ in 1 to 2 years (Table 1). Individual experience, knowledge, and resources are more important than nutrient relationships. The DGEM regards a recommendation grade of $\mathrm{B}$ rather than 0 as justified for this procedure.

To attain the therapeutic objective, the use of formula products supplying 800 to $1200 \mathrm{kcal} /$ day may be considered (EL 1, RG 0). This form of nutrition is recommended for persons with a BMI of $30 \mathrm{~kg} / \mathrm{m}^{2}$ or more for a maximum of 12 weeks; weight loss of 0.5 to 2.0 $\mathrm{kg} /$ week may be expected (17). This treatment should be carried out under a physician's supervision because of the increased risk of side effects (EL 1, RG A). In the opinion of the DGEM, formula diets have been well investigated in high-quality cohort studies and for this reason a recommendation grade of $\mathrm{A}$ rather than 0 is favored. Formula diets are the most effective diet method for initial weight reduction.

Extremely one-sided diets should not be recommended because of the high medical risks they entail and their lack of long-term success (EL 4, RG A). Diets involving extreme nutrient distributions (e.g., so-called crash diets) are widely followed in Germany. No robust studies on their effectiveness and safety have been published. Since their effectiveness and safety are unknown, they cannot be recommended.

\section{Increased exercise}

Effective weight loss requires $>150 \mathrm{~min} /$ week of exercise with an energy consumption rate of 1200 to $1800 \mathrm{kcal} /$ week (8). Strength training alone is not very effective for weight reduction (EL 2-4, RG B) (18). The amount of energy used up during exercise is often overestimated. When large muscle groups are used, the intensity is moderate to high, and the exercise work is of long duration, weight loss can be expected. Wellcontrolled studies and meta-analyses show a weight reduction of about $2 \mathrm{~kg}$ and about a $6 \%$ loss of abdominal fat in 6 to 12 months (Table 2).

It should be ascertained that overweight and obese persons do not have any contraindications to additional physical activity. This is particularly the case for patients with a BMI of $35 \mathrm{~kg} / \mathrm{m}^{2}$ or higher (EL 4, RG B).

Overweight and obese persons should have the health advantages (metabolic, cardiovascular, and psychosocial) of physical activity explained to them, which accrue irrespective of loss of weight (EL 4, RG A). Even in obese individuals, the health value of increased exercise is seen in more than just a loss of weight (23). 


\section{Interventions for behavior modification}

Interventions based on a behavioral approach, in a group or individual setting, should form part of a program of weight reduction (EL 1, RG A). The intervention should be aimed primarily at altering lifestyle in terms of nutrition and exercise and may be carried out by qualified non-psychotherapists. If the symptoms accompanying overweight or obesity are more serious (e.g., co-morbid depression, eating disorders, motivation problems), psychiatrists or psychotherapists should be involved in the patient management, and patients should be supported in their dietary therapy and exercise (24).

Various strategies are available for intervention. They should be adapted to the individual situation and the wishes of the patient involved (25) (Box).

\section{Weight reduction program}

Obese patients should be offered weight reduction programs that are adapted to their individual situation and targeted at the therapeutic goals (EL 4, RG B). The weight reduction programs should include the elements of the basic program (exercise, diet, and behavioral
BOX

\section{Strategies for weight reduction may have the fol- lowing psychotherapeutic elements (EL 1-2. RG 0):}

- Self-observation of behavior and progress (body weight, amount eaten, exercise)

- Practicing flexible, controlled eating and exercise behavior (as opposed to rigid behavioral control)

- Stimulus control (stimulus = external trigger for eating)

- Strategies for handling returning weight gain

- Social support

- Cognitive restructuring (modification of dysfunctional thought patterns)

- Agreeing goals

- Problem-solving training/conflict resolution training

- Social competence training/assertiveness training

- Reinforcement strategies (e.g., rewarding changes)

- Preventing relapse

\section{TABLE 3}

Commercial programs for weight reduction in Germany for which at least one study has been published in a peer-reviewed journal*

\begin{tabular}{|c|c|c|c|c|c|c|}
\hline & $\begin{array}{l}\text { "Ich nehme ab"*1 } \\
\text { (DGE) }\end{array}$ & $\begin{array}{l}\text { "Abnehmen mit } \\
\text { Genuss" }\end{array}$ & Weight Watchers & Bodymed & M.O.B.I.L.I.S & Optifast-52 \\
\hline Mean BMI $\left(\mathrm{kg} / \mathrm{m}^{2}\right)$ & Around 30 & 31 & 31,4 & 33,4 & 35,7 & 40,8 \\
\hline $\begin{array}{l}\text { Number of } \\
\text { participants }\end{array}$ & Various studies & 45869 & $\begin{array}{c}772 \\
\text { (377 Weight } \\
\text { Watchers) }\end{array}$ & 665 & 5025 & 8296 \\
\hline Formula diet & No & No & No & Yes & No & Yes \\
\hline Probands weighed & Yes & Self-reported & Yes & Yes & Yes & Yes \\
\hline$\Delta \mathrm{kg}$ (1 year) & Not stated & Not stated & $\begin{array}{c}-5.1 \text { (LOCF, } \\
\text { Weight Watchers) } \\
-2.3 \text { (LOCF, } \\
\text { controls) }\end{array}$ & -9.8 (LOCF) & -5.1 (BOCF) & -16.4 (LOCF) \\
\hline$\Delta \mathrm{kg}$ (1 year) women & $-2.3 /-2.0 /-1.3$ & -2.2 (BOCF) & Not stated & Not stated & -5.0 (BOCF) & -15.2 (LOCF) \\
\hline$\Delta \mathrm{kg}$ (1 year) men & -4.1 & -2.9 (BOCF) & Not stated & Not stated & -5.9 (BOCF) & -19.4 (LOCF) \\
\hline Dropouts & $16 \%-35 \%$ & $51 \%$ & $\begin{array}{c}39 \% \\
\text { (Weight Watchers) }\end{array}$ & $23 \%$ & $14 \%$ & $42 \%$ \\
\hline Type & $\mathrm{RCT}$ & Observation & $\mathrm{RCT}$ & Observation & Observation & Observation \\
\hline Study quality & $\begin{array}{l}\text { RCT studies with and } \\
\text { without personal } \\
\text { counseling }\end{array}$ & $\begin{array}{l}\text { All participants in } \\
\text { Germany from } 2006 \\
\text { to } 2010\end{array}$ & $\begin{array}{l}\text { RCT outcome in } \\
\text { comparison to stan- } \\
\text { dard advice from } \\
\text { doctor }\end{array}$ & $\begin{array}{c}\text { Selected sample } \\
\text { (from approx. } 500 \\
\text { Bodymed centers in } \\
\text { Germany) }\end{array}$ & $\begin{array}{l}316 \text { groups from } \\
2004 \text { to } 2011\end{array}$ & $\begin{array}{l}\text { All participants, all } \\
\text { centers in Germany } \\
\text { from } 1999 \text { to } 2007\end{array}$ \\
\hline Reference & (26) & (27) & (28) & (29) & (30) & (31) \\
\hline
\end{tabular}

* Where several publications were available for one program, the publication in the journal with the highest impact factor was chosen; DGE, Deutsche Gesellschaft für Ernährung (German Nutrition Society); AOK, Allgemeine Ortskrankenkasse (a large general statutory health insurance company); BMI, body mass index; LOCF, last observation carried forward; BOCF, baseline observation carried forward; RCT, randomized controlled trial

*1 "Let's lose weight"

*2 "Enjoy losing weight" 


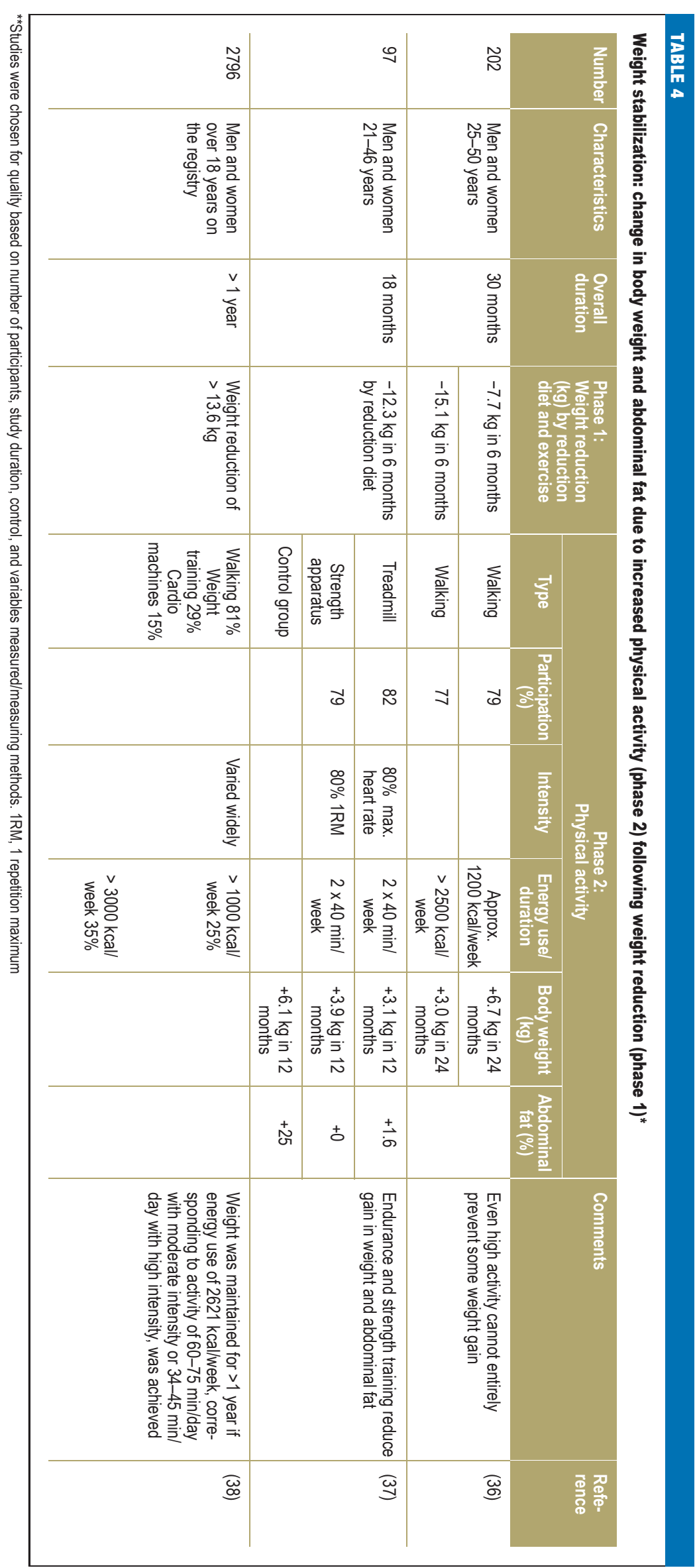

therapy) (EL 1-2, RG A). Table 3, which gives an overview, includes only programs for which published data are available.

The DGEM mentions that obese persons should only be offered programs that have received a positive assessment, which are geared to the individual situation and the therapeutic goals. Programs whose effectiveness is not clear, because (for example) there are no measured data to show the course of body weight over time, should be excluded.

\section{Weight-reducing drugs}

Drug therapy should only be carried out in combination with a basic program (diet, exercise, behavioral therapy). The only drug that may be considered is orlistat (EL 1, RG A). Orlistat treatment is indicated in patients with a BMI above $28 \mathrm{~kg} / \mathrm{m}^{2}$ who also have other risk factors or co-morbidities, or with a BMI $\geq 30 \mathrm{~kg} / \mathrm{m}^{2}$ who have less than $5 \%$ weight loss after 6 months on the basic program (32).

Patients with type 2 diabetes mellitus and a BMI $\geq 30$ $\mathrm{kg} / \mathrm{m}^{2}$ may, if their glycemic control is inadequate on metformin, also use GLP-1 mimetics and SGLT2 inhibitors (EL 1, RG 0). These drugs should be considered as an alternative to antidiabetic drugs that promote weight increase, such as sulfonylureas, glinides, glitazones, and insulin (33).

The DEGAM states that insufficient study data exist for GLP-1 analogs in relation to clinical end points. It points out that they may be associated with an increased risk of pancreatic disease.

Drugs such as amphetamines, diuretics, human chorionic gonadotrophin (HCG), testosterone, thyroxine, and growth hormones, and medical products / dietary supplements should not be recommended as a way to lose weight (EL 4, RG A). The drugs have an unacceptable risk-benefit ratio, and in regard to the medical products and dietary supplements, evidence of their effectiveness is lacking.

\section{Long-term weight stabilization}

Measures to stabilize body weight long term should take into account aspects of diet, exercise, and behavioral therapy together with the motivation of the patient involved (EL 4, RG B).

To support weight stabilization, treatments and consultations should be made available over the long term after successful weight loss, and should include cognitive behavioral therapy (EK 1, RG A) (34).

Patients should be advised, after a period of weight reduction, to maintain an increased level of physical exercise (EL 1-2, RG A). Experience has shown that almost all patients who maintain their weight after a period of weight loss have remained or become physically active (35). After losing 7 to $14 \mathrm{~kg}$, physically active persons regain half their lost weight within 1 to 2 years (Table 4).

Patients should be told that a low-fat diet will help prevent weight regain (EL 1-2, RG B) (39). In persons who lost 12 to $24 \mathrm{~kg}$ on a very low calorie diet, weight 
Weight maintenance after weight reduction by change of eating habits*

\begin{tabular}{|c|c|c|c|c|}
\hline \multirow{2}{*}{$\begin{array}{l}\text { Studies/ } \\
\text { meta-analysis }\end{array}$} & \multirow[t]{2}{*}{ Phase 1: Weight loss } & \multicolumn{2}{|c|}{ Phase 2: Weight maintenance } & \multirow[t]{2}{*}{ Reference } \\
\hline & & Length of follow-up & Weight change & \\
\hline $\begin{array}{l}\text { Meta-analysis } \\
\text { of } 29 \text { US studies }\end{array}$ & $\begin{array}{l}\text { Average VLCD: } 24.1 \mathrm{~kg} \\
\text { REMD: } 8.8 \mathrm{~kg}\end{array}$ & $\begin{array}{l}4.5 \text { years (VLCD: } 55 \% \text { of } \\
\text { initial participants, } \\
\text { LCD: } 80 \% \text { of participants) }\end{array}$ & $\begin{array}{c}\text { VLCD: }-6.6 \%(-5.6 \text { to }-7.5 \%) \\
\text { of initial weight } \\
\text { REBD: } 2.1 \%(1.6 \text { to } 2.7 \%) \\
\text { no difference between sexes; } \\
\text { with more activity: }-12.5 \% \\
(-11.2 \text { to }-13.7 \%)\end{array}$ & (40) \\
\hline $\begin{array}{l}\text { Meta-analysis } \\
\text { of } 46 \text { RCTs } \\
\text { (Dietary counseling vs. } \\
\text { "usual care") }\end{array}$ & $\begin{array}{c}\text { Mean weight loss of } \\
1.9 \text { BMI units after } \\
12 \text { months (corresponds to }-6 \% \text { ) }\end{array}$ & 6 to 48 months & $\begin{array}{c}\text { Regain of } \\
\text { body weight by } 0.02 \text { to } \\
0.03 \mathrm{BMI} \text { units per month } \\
\text { (corresponds to approx } 1 \mathrm{~kg} / \mathrm{year} \text { ) }\end{array}$ & (14) \\
\hline \multirow[t]{6}{*}{$\begin{array}{l}\text { Meta-analysis } \\
\text { of } 20 \text { RCTs }\end{array}$} & \multirow[t]{6}{*}{$\begin{array}{l}\text { Weight loss of } \\
12.3 \mathrm{~kg} \text { on VLCD or LCD } \\
(<1000 \mathrm{kcal} / \mathrm{day})\end{array}$} & 18 to 36 months & $\begin{array}{c}\text { Drugs: } \\
\text { Effect of }+3.5 \mathrm{~kg}, 3 \mathrm{RCTs}, \\
658 \text { participants }\end{array}$ & \multirow[t]{6}{*}{ (e1) } \\
\hline & & 10 to 26 months & $\begin{array}{l}\text { Meal replacements: } \\
+3.9 \mathrm{~kg}, 4 \text { studies, } \\
372 \text { participants }\end{array}$ & \\
\hline & & 3 to 12 months & $\begin{array}{l}\text { High-protein diet: } \\
+1.5 \mathrm{~kg}, 6 \text { studies, } \\
865 \text { participants }\end{array}$ & \\
\hline & & 6 months & $\begin{array}{l}\text { Other types of diet: } \\
+1.2 \mathrm{~kg}, 3 \text { studies } \\
564 \text { participants }\end{array}$ & \\
\hline & & 3 to 14 months & $\begin{array}{l}\text { Dietary supplements: } \\
\text { +/-0 kg, } 6 \text { studies, } \\
261 \text { participants }\end{array}$ & \\
\hline & & 6 to 12 months & $\begin{array}{l}\text { Exercise program: } \\
+0.8 \mathrm{~kg}, 5 \text { studies, } \\
347 \text { participants }\end{array}$ & \\
\hline
\end{tabular}

*Meta-analyses were chosen for quality based on number of participants, duration of studies, control intervention, and variables measured/measuring methods. VLCD, very low calorie diet (<800 kcal/day); LCD, low calorie diet (<1000 kg/day); REMD, reduced-energy mixed diet (energy deficit 500-600 kcal/day); RCT, randomized controlled trial

regain of $<5 \mathrm{~kg}$ was seen after 1 to 2 years on a reduced-energy balanced diet (Table 5).

Regular weighing contributes to better weight stabilization after successful weight loss (EL 4, RG B) (e2).

\section{Surgical intervention in extremely obese patients}

For extremely obese patients, surgical intervention should be considered (EL 1-3, RG A). Compared to conservative treatment, surgical treatment is more effective in terms of body fat reduction, improvement of obesity-related diseases, and reduction of mortality risk (e3-e5) (Figure 2).

Obesity surgery is indicated according to BMI as follows, if all conservative treatment methods have been unsuccessful (EL 4, RG A):

- Grade III obesity (BMI $\geq 40 \mathrm{~kg} / \mathrm{m}^{2}$ ) or

- Grade II obesity (BMI $\geq 35 \mathrm{~kg}$ and $<40 \mathrm{~kg} / \mathrm{m}^{2}$ ) with significant co-morbidities (e.g., type 2 diabetes) or

- Grade I obesity (BMI $>30$ and $<35 \mathrm{~kg} / \mathrm{m}^{2}$ ) in patients with type 2 diabetes (special cases)
If multimodal conservative therapy for 6 months leads to $\leq 10 \%$ weight loss in patients with a BMI of 35 to $39.9 \mathrm{~kg} / \mathrm{m}^{2}$ and $\leq 20 \%$ in those with a BMI of $\geq 40$ $\mathrm{kg} / \mathrm{m}^{2}$, surgery should be considered (1). The DGEM states: surgery is indicated in patients with a BMI $\geq 40$ $\mathrm{kg} / \mathrm{m}^{2}$ if $\leq 10 \%$ of the initial weight has been lost. For patients with type 2 diabetes, the recommendation grade is $\mathrm{B}$, as the data are insufficient.

Surgical treatment can also be given as a primary therapy, without any preceding conservative treatment, if conservative treatment is judged to have no chance of success or the patient's health does not allow surgery to be delayed in order to attempt improvement by weight reduction (EL 4, RG 0). Patients with severe concomitant disease, a BMI $\geq 50 \mathrm{~kg} / \mathrm{m}^{2}$, and difficult psychosocial circumstances are eligible. The DGEM regards surgery as indicated in patients who are immobile, in whom diet-based treatment has failed, and in those with a high insulin requirement.

Before surgery, patients should undergo an assessment that includes metabolic, cardiovascular, psychosocial, and dietary details (EL 4, RG A). After bariatric 
Commonly used surgical methods to treat extreme obesity

a) Sleeve gastrectomy

b) Gastric banding

c) Gastric bypass

(From: Runkel N, et al.: Clinical practice guideline: Bariatric surgery. Dtsch Arztebl Int 2011; 108(20): 341-6).

\section{FIGURE 2}
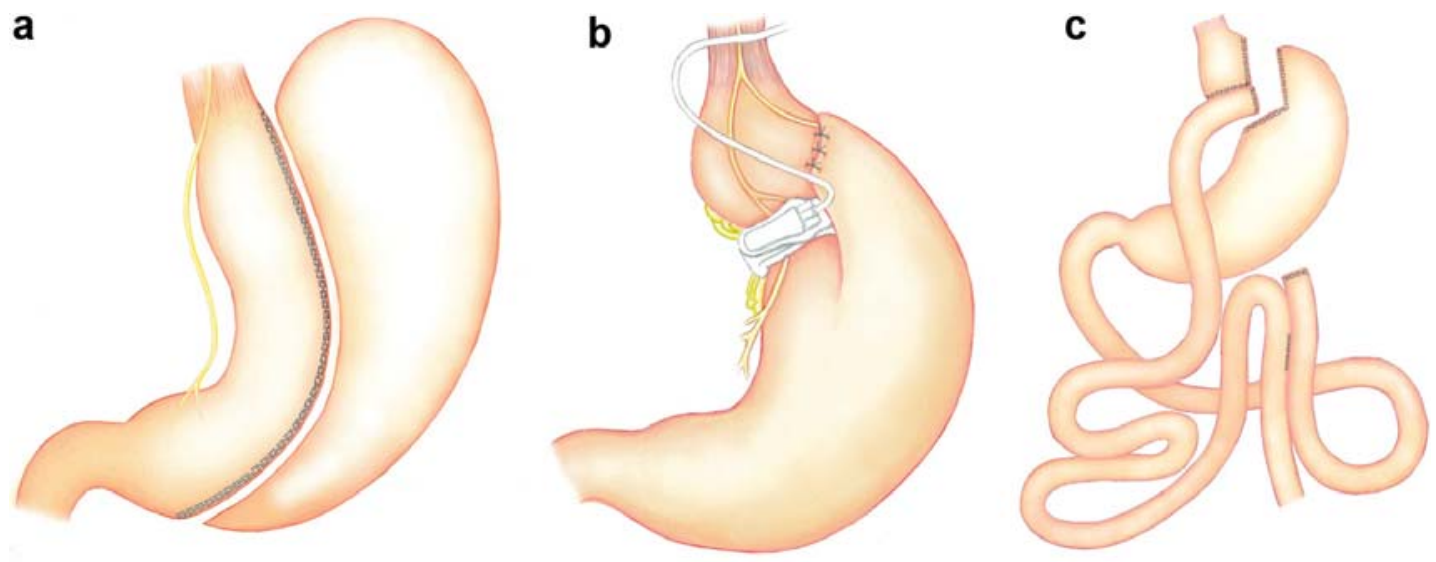

surgery, lifelong interdisciplinary follow-up is required (EL 4, RG A) (e6). For quality assurance, patients who undergo weight loss surgery should be entered in a central national register (EL 4, RG B).

\section{Conflict of interest statement \\ Professor Hauer has received consultancy fees from Weight Watchers Inter- national and Apothecom (advisory boards). He has received third-party funding from Weight Watchers International and from Riemser GmbH and Certmedica. Professor Wirth has received consultancy fees from Riemser $\mathrm{GmbH}$. \\ Professor Wabitsch has received consultancy fees from Johnson and Johnson Medical GmbH. \\ Manuscript received on 17 July 2014, revised version accepted on 23 July 2014.}

Translated from the original German by Kersti Wagstaff, MA.

\section{KEY MESSAGES}

- Obesity $\left(\mathrm{BMI} \geq 30 \mathrm{~kg} / \mathrm{m}^{2}\right)$ is a chronic disease.

- The high prevalence of obesity in adults $(24 \%)$ means that effective prevention and treatment are required.

- For weight loss in obesity, and stabilization at the reduced weight, a diet resulting in an energy deficit of 500 $\mathrm{kcal} /$ day is effective. A low-energy diet is recommended; the ratios between macronutrients (fat, carbohydrates, protein) is of secondary importance.

- Behavior modification supports changes in diet and exercise in everyday living.

- In extremely obese patients, surgical treatment should be considered.

\section{REFERENCES}

1. World Health Organization: Obesity - preventing and managing the global epidemic. Report of a WHO Consultation on obesity. Technical Report Series 894. Geneva 2000.

2. Kurth BM: Erste Ergebnisse aus der „Studie zur Gesundheit Erwachsener in Deutschland" (DEGS). Bundesgesundheitsblatt Gesundheitsforschung Gesundheitsschutz 2012; 55: 980-90.

3. Statistisches Bundesamt: Mikrozensus - Fragen zur Gesundheit Körpermaße der Bevölkerung. 2011 [cited: 2013].

4. Bes-Rastrollo M, van Dam RM, Martinez-Gonzalez MA, Li TY, Sampson LL, Hu FB: Prospective study of dietary energy density and weight gain in women. Am J Clin Nutr 2008; 88: 769-77.

5. Sayon-Orea C, Martinez-Gonzalez MA, Bes-Rastrollo M: Alcohol consumption and body weight: a systematic review. Nutr Rev 2011; 69: 419-31.

6. Rosenheck R: Fast food consumption and increased caloric intake: a systematic review of a trajectory towards weight gain and obesity risk. Obes Rev 2008; 9: 535-47.

7. Vartanian LR, Schwartz MB, Brownell KD: Effects of soft drink consumption on nutrition and health: a systematic review and metaanalysis. Am J Public Health 2007; 97: 667-75.

8. Donnelly JE, Blair SN, Jakicic JM, Manore MM, Rankin JW, Smith BK: American College of Sports Medicine Position Stand: Appropriate physical activity intervention strategies for weight loss and prevention of weight regain for adults. Med Sci Sports Exerc 2009; 41: $459-71$.

9. Witham MD, Avenell A: Interventions to achieve long-term weight loss in obese older people: a systematic review and meta-analysis. Age Ageing 2010; 39: 176-84.

10. Astrup A, Grunwald GK, Melanson EL, Saris WH, Hill JO: The role of low-fat diets in body weight control: a meta-analysis of ad libitum dietary intervention studies. Int J Obes Relat Metab Disord 2000; 24: $1545-52$.

11. Nordmann AJ, Nordmann A, Briel M, et al.: Effects of low-carbohydrate vs low-fat diets on weight loss and cardiovascular risk factors: a meta-analysis of randomized controlled trials. Arch Intern Med 2006; 166: 285-93.

12. Shai I, Schwarzfuchs D, Henkin Y, et al.: Weight loss with a lowcarbohydrate, Mediterranean, or low-fat diet. N Engl J Med 2008; 359: 229-4. 
13. Sacks FM, Bray GA, Carey VJ, et al.: Comparison of weight-loss diets with different compositions of fat, protein, and carbohydrates. N Engl J Med 2009; 360: 859-73.

14. Dansinger ML, Tatsioni A, Wong JB, Chung M, Balk EM: Metaanalysis: the effect of dietary counseling for weight loss. Ann Intern Med 2007; 147: 41-50.

15. Schwingshackl L, Hoffmann G: Long-term effects of low-fat diets either low or high in protein on cardiovascular and metabolic risk factors: a systematic review and meta-analysis. Nutr J 2013; 12 48.

16. Esposito K, Kastorini CM, Panagiotakos DB, Guigliano D: Mediterranean diet and weight loss: meta-analysis of randomized controlled trials. Metab Syndr Relat Disord 2011; 9: 1-12.

17. Clinical Guidelines on the Identification, Evaluation, and Treatment of Overweight and Obesity in Adults - The Evidence Report: National Institutes of Health. Obes Res 1998; 6: 51-209.

18. Ismail, I, Keating SE, Baker MK, et al.: A systematic review and meta-analysis of the effect of aerobic vs:resistance exercise training on visceral fat. Obes reviews 2012; 13: 68-91.

19. McTiernan A, Sorensen B, Irwin ML, et al.: Exercise effect on weight and body fat in men and women. Obesity (Silver Spring) 2007; 15: 1496-512.

20. Slentz CA, Bateman LA, Willis LH, et al.: Effects of aerobic vs: resistance training on visceral and liver fat stores, liver enzymes, and insulin resistance by HOMA in overweight adults from STRRIDE AT/ RT. Am J Physiol Endocrinol Metab 2011; 301: E1033-E9.

21. Thorogood A, Mottillo S, Shimony A, et al.: Isolated aerobic exercise and weight loss: a systematic review and meta-analysis of randomized controlled trials. Am J Medicine 2011; 124: 747-55.

22. Shaw G, Gennat H, O'Rourke P, Del Mar C: Exercise for overweight or obesity. Cochrane Date Base Syst Rev 2006; CD003817.

23. Göhner W, Schlatterer M, Seelig H, Frey I, Berg A, Fuchs R: Twoyear follow-up of an interdisciplinary cognitive-behavioral intervention program for obese adults. J Psychol 2012; 146: 371-91.

24. Anderson JW, Reynolds LR, Bush HM, Rinsky JL, Washnock C: Effect of a behavioral/nutritional intervention program on weight loss in obese adults: a randomized controlled trial. Postgrad Med 2011; 123: 205-13.

25. Shaw K, O'Rourke P, Del MC, Kenardy J: Psychological interventions for overweight or obesity. Cochrane Database Syst Rev 2005; CD003818.

26. Scholz GH, Flehming G, Scholz M, et al.: Evaluation des Selbsthilfeprogramms „Ich nehme ab“: Gewichtsverlust, Ernährungsmuster und Akzeptanz nach einjähriger beratergestützter Intervention be übergerwichtigen Personen. Ernährungs-Umschau 2005; 52: 226-31.

27. Austel A, Podzuweit F, Tempelmann A, Stotz-Jonas B, Ellrott T: Evaluation eines tailorisierten computergestützten Gewichtsmanagementsprogramms mit 46.000 Teilnehmern. Obes Facts 2012 5: 28-9.

28. Jebb SA, Ahern AL, Olson AD, et al.: Primary care referral to a commercial provider for weight loss treatment versus standard care: a randomised controlled trial. Lancet 2011; 378: 1485-92.

29. Walle H, Becker C: LEAN-Studie II: 1-Jahresergebnisse eines ambulanten, ärztlich betreuten Ernährungskonzepts. Adipositas 2011; $1: 15-24$.

30. Lagerstrom D, Berg A, Haas U, et al.: Das M.O.B.I.L.I.S. Schulungsprogramm: Bewegungstherapie und Lebensstilintervention bei Adipositas und diabetes. Diabet Aktuel 2013; 11: 5-11.

31. Bischoff SC, Damms-Machado A, et al.: Multicenter evaluation of an interdisciplinary 52-week weight loss program for obesity with regard to body weight, comorbidities and quality of lifea prospective study. Int J Obes 2012; 36: 614-24.

32. Sjöstrom L, Rissanen A, Andersen T, et al.: Randomised placebocontrolled trial of orlistat for weight loss and prevention of weight regain in obese patients. European Multicentre Orlistat Study Group. Lancet 1998; 352: 167-72.
33. Monami M, Dicembrini I, Marchionni N, Rotella CM, Mannucci E: Effects of glucagon-like Peptide-1 receptor agonists on body weight: a meta-analysis. Exp Diabetes Res 2012; 2012: 672658.

34. Ohsiek S, Williams M: Psychological factors influencing weight loss maintenance: an integrative literature review. J Am Acad Nurse Pract 2011; 23: 592-601.

35. Klem ML, Wing RR, McGuire MT, Seagle HM, Hill JO: A descriptive study of individuals successful at long-term maintenance of substantial weight loss. Am J Clin Nutr 1997; 66: 239-46.

36. Tate DF, Jeffery RW, Sherwood NE, Wing RR: Long-term weight losses associated with prescription of higher physical activitry goals: Are higher levels of physical activity protective against weight regain? Am J Clin Nutr 2007; 85: 954-9.

37. Hunter GR, Brock DW, Byrne NM, et al.: Exercise training prevents regain of visceral fat for 1-year following weight loss. Obesity 2010 18: $690-5$.

38. Catenacci VA, Ogden LG, Stuht J, et al.: Physical activity patterns in the National Weight Control Registry. Obesity 2008; 16: 153-61.

39. Toubro S, Astrup A: Randomised comparison of diets for maintaining obese subjects' weight after major weight loss: ad lib, low fat, high carbohydrate diet v fixed energy intake. BMJ 1997; 314: 29-34.

40. Anderson JW, Konz EC, Frederich RC, Wood CL: Long-term weightloss maintenance: a meta-analysis of US studies. Am J Clin Nutr 2001: 74: 579-84.

\section{Corresponding author}

Prof. Dr. med. Alfred Wirth

Sonnenhang 1a

49214 Bad Rothenfelde, Germany

wirthbr@t-online.de 


\section{CLINICAL PRACTICE GUIDELINE}

\section{The Prevention and Treatment of Obesity}

Alfred Wirth, Martin Wabitsch, Hans Hauner

\section{eREFERENCES}

e1. Johansson K, Neovius M, Hemmingsson E: Effects of anti-obesity drugs, diet, and exercise on weight-loss maintenance after a very-low-calorie diet or low-calorie diet: a systematic review and meta-analysis of randomized controlled trials. Am J Clin Nutr 2014; 99: 14-23.

e2. Butryn ML, Phelan S, Hill JO, Wing RR: Consistent self-monitoring of weight: a key component of successful weight loss maintenance. Obesity (Silver Spring) 2007; 15: 3091-6.

e3. Sjostrom L, Narbro K, Sjostrom CD, et al.: Effects of bariatric surgery on mortality in Swedish obese subjects. N Engl J Med 2007; 357: 741-52.

e4. Dixon JB, Zimmet P, Alberti KG, Rubino F: Bariatric surgery: an IDF statement for obese Type 2 diabetes. Diabet Med 2011; 28 : $628-42$.

e5. Schauer PR, Kashyap SR, Wolski K, et al.: Bariatric surgery versus intensive medical therapy in obese patients with diabetes. N Engl J Med 2012; 366: 1567-76.

e6. Slater GH, Ren CJ, Siegel N, et al.: Serum fat-soluble vitamin deficiency and abnormal calcium metabolism after malabsorptive bariatric surgery. J Gastrointest Surg 2004; 8: 48-55. 


\section{Participating societies, organizations, and experts}

The Guideline members represent the following medical societies and organizations

- German Obesity Association (DAG, Deutsche Adipositas-Gesellschaft)

- Prof. H. Hauner

- Prof. D. Kunze

- Dr. M. Teufel

- Prof. M. Wabitsch

- Prof. A. Wirth

- German Diabetes Association (DDG, Deutsche Diabetes-Gesellschaft)

- Prof. N. Stefan

- German Society of Nutritional Medicine (DGEM, Deutsche Gesellschaft für Ernährungsmedizin)

- Prof. S.C. Bischoff

- German Nutrition Society (DGE, Deutsche Gesellschaft für Ernährung)

- Dr. T. Ellrott

- German College of General Practitioners and Family Physicians (DEGAM, Deutsche Gesellschaft für Allgemeinmedizin)

- Dr. C. Heintze

- German Society of Sports Medicine and Prevention (DGSP, Deutsche Gesellschaft für Sportmedizin und Prävention)

- Prof. A. Berg

- German Eating Disorder Society (DGESS, Deutsche Gesellschaft für Essstörungen)

- German College for Psychosomatic Medicine (DKPM, Deutsches Kollegium für Psychosomatische Medizin)

- German Society of Psychosomatic Medicine and Medical Psychotherapy (DGPM, Deutsche Gesellschaft für Psychosomatische Medizin)

- Dr. M. Teufel

- Surgical Working Group for Adiposity Therapy (CAADIP, Chirurgische Arbeitsgemeinschaft für Adipositastherapie) of the German Society for General and Visceral Surgery (DGAV, Deutsche Gesellschaft für Allgemein- und Viszeralchirurgie)

- Prof. M. Colombo-Benkmann

- Obesity Surgery Patient Support Group (AcSDeV, Adipositaschirurgie-Selbsthilfe Deutschland)

- U. Kanthak

- Standing Commission on the Maintenance and Updating of DAG Guidelines (Ständige Kommission zur Pflege und Aktualisierung der DAG-Leitlinien) - Dr. A. Moss
eTABLE

Classification (SIGN 2010) and evaluation of evidence. Evidence levels (EL) were divided into sublevels using + and - signs.

\begin{tabular}{|c|c|c|}
\hline \multicolumn{2}{|c|}{ Evidence level } & \multirow{2}{*}{$\begin{array}{l}\text { Description } \\
\text { High-quality meta-analyses, systematic reviews of RCTs, } \\
\text { or RCTs with a very low risk of bias }\end{array}$} \\
\hline 1 & $1++$ & \\
\hline & $1+$ & $\begin{array}{l}\text { Well-conducted meta-analyses, systematic reviews of } \\
\text { RCTs, or RCTs with a low risk of bias }\end{array}$ \\
\hline & $1-$ & $\begin{array}{l}\text { Meta-analyses, systematic reviews of RCTs, or RCTs } \\
\text { with a high risk of bias }\end{array}$ \\
\hline \multirow[t]{3}{*}{2} & $2++$ & $\begin{array}{l}\text { High quality systematic reviews of case control or cohort } \\
\text { studies } \\
\text { High quality case control or cohort studies with a very } \\
\text { low risk of confounding or bias and a high probability } \\
\text { that the relationship is causal }\end{array}$ \\
\hline & $2+$ & $\begin{array}{l}\text { Well conducted case control or cohort studies with a low } \\
\text { risk of confounding or bias and a moderate probability } \\
\text { that the relationship is causal }\end{array}$ \\
\hline & $2-$ & $\begin{array}{l}\text { Case control or cohort studies with a high risk of con- } \\
\text { founding or bias and a significant risk that the relations- } \\
\text { hip is not causal }\end{array}$ \\
\hline 3 & 3 & Nonanalytic studies, e.g., case reports, case series \\
\hline \multirow[t]{10}{*}{4} & 4 & Expert opinion \\
\hline & $\begin{array}{l}\text { Recommendation } \\
\text { grade (RG) }\end{array}$ & Description \\
\hline & $A$ & Strong recommendation \\
\hline & $\mathrm{B}$ & Recommendation \\
\hline & 0 & No recommendation \\
\hline & Consensus strength & Percentage of participants in agreement \\
\hline & Strong consensus & $>95 \%$ of participants \\
\hline & Consensus & $>75-95 \%$ of participants \\
\hline & Majority agreement & $>50-75 \%$ of participants \\
\hline & No consensus & $<50 \%$ of participants \\
\hline
\end{tabular}

$\mathrm{RCT}$, randomized controlled trial 


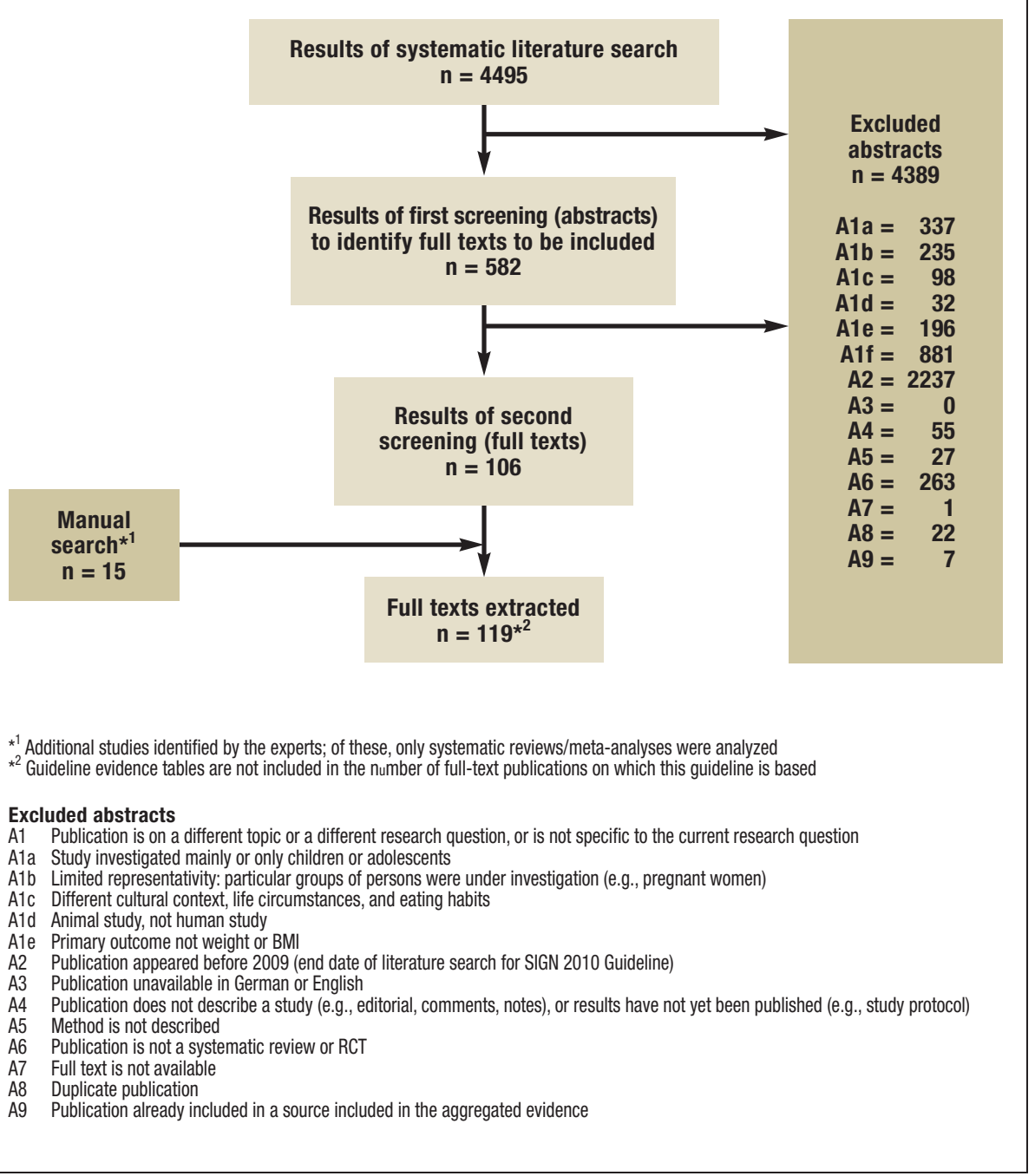

